\title{
Lukács e Heidegger diante da ontologia e da revolução social : entrevista com Vitor Bartoletti Sartori
}

$\mathrm{A}_{\text {Lukács (I885-197I) compartilharam muitas afinidades: pertenceram a mesma }}$ geração; cultivavam a mesma paixão pelo espirito alemão; padeceram dos dramas bumanos e das reverberaçôes das duas Guerras Mundiais (1914-19I8; 1939-1945); e deixaram como legado duas ontologias e duas criticas radicais à modernidade. Porém, um olhar mais atento sobre a obra e a vida de ambos demonstrará que nada se desassemelha mais deles do que eles mesmos. De lados opostos da história, as obras de Heidegger e Lukács permanecem instigantes e inspiradoras para as sucessivas gerações de filósofos que os procederam, como também, para a geração presente.

Nesta entrevista concedida a Wesley Sousa e Henrique Coelho, ${ }^{2}$ Vitor Bartoletti Sartori, ${ }^{3}$ professor adjunto da Universidade Federal de Minas Gerais (UFMG) e "sanfranciscano" atípico, resenhou sua trajetória acadêmica e seu livro mais recente, Ontologia nos extremos (2019), baseado na primeira parte de sua tese de doutorado, Alienação, ontologia e técnica (2013), onde examinou as divergências e aproximaçôes das ontologias de Heidegger e Lukács. Avesso à pesquisa desinteressada, Sartori demonstrou ao longo da entrevista o quanto as obras de Heidegger e Lukács permanecem atuais e permitem, se não solucionar, ao menos encontrar as perguntas corretas diante dos desafios existenciais do presente. Advogando, assim, que ambos os filósofos merecem

I Licenciando em Filosofia pela Universidade Federal de São João del-Rei (UFSJ). Ex-bolsista do Programa Institucional de Bolsa de Iniciação à Docência (PIBID) pela Coordenação de Aperfeiçoamento de Pessoal de Nível Superior (CAPES). ORCID: «http://orcid.org/oooo-ooor-7638-5275». Contato: wesleysousa666@outlook.com.

2 Doutorando em Administração pela Faculdade de Ciências Econômicas da Universidade Federal de Minas Gerais (FACE-UFMG). Professor de Sociologia e Teoria Geral da Administração. ORCID: «http://orcid.org/oooo-0003-3657-I4I4». Contato: rickcoelholda@hotmail.com.

3 Mestre em História Social pela Pontifícia Universidade Católica de São Paulo (PUC-SP) e Doutor em Teoria e Filosofia do Direito pela Universidade de São Paulo (USP). ORCID: «https://orcid.org/oooo-oooI-95709968». Contato: vitorbsartori@gmail.com. 


\section{REVISTA ANGELUS NOVUS}

(re)leituras, investigaçôes e debates. Ademais, com um tom franco e direto, Sartori também expôs sua crítica a miséria intelectual do habitat acadêmico, a fragmentação do conbecimento em departamentos cada vez mais ensimesmados e a necessidade de verdadeiros e consistentes debates cientificos, indispensáveis para resgatar nosso pais de seu atual atoleiro politico, econômico, social e cultural. Segundo Sartori, as criticas radicais à modernidade de Heidegger e Lukács seriam incontornáveis para este fim. ${ }^{4}$

Palavras-chave Ontologia - Lukács - Heidegger - Determinação social do pensamento Revolução social.

Lukács and Heidegger on Ontology and Social Revolution: Interview with Vitor Bartoletti Sartori

Keywords Ontology - Lukács - Heidegger - Social Determination of Thought - Social Revolution.

Lukács y Heidegger delante de la ontología y de la revolución social: entrevista con Vitor Bartoletti Sartori

Palabras clave Ontología - Lukács - Heidegger - Determinación social de lo pensamiento Revolución social.

\section{Submissão}

$$
03 / 02 / 202 \mathrm{I}
$$

\section{Aprovação}

I4/04/202I

Publicação

16/04/2021

4 A versão em áudio da entrevista encontra-se disponível no podcast Ontocast (Publicado em 2 abr. 202I Disponível em:
si=jXae_Vr6TCqI7eDrjsNd_w»). 


\section{WESLEY SOUSA E HENRIQUE COELHO}

Professor Sartori, para iniciar nossa conversa, seria interessante para alinhá-la, comentar um pouco sobre como e por que veio a pesquisar o pensamento de Heidegger a partir do pensamento marxista de Lukács em seu doutorado. Como foi esse processo sob a orientação de Jeannette Maman?

\section{VITOR BARTOLETTI SARTORI}

Gostaria de começar dizendo que há muitos aspectos em sua pergunta. Passar por todos eles seria impossível no tempo que dispomos. No entanto, destacaria dois de imediato. Um deles diz respeito a uma dimensão pessoal, ligado à minha formação na Universidade de São Paulo. Ou seja, tem-se o fato de eu ter me formado na tradicional Faculdade de Direito no Largo de São Francisco, em São Paulo. Outro aspecto passa pelo modo como se colocava o pensamento de esquerda na época, e, diria eu, em grande parte, ainda hoje. Estes elementos estão conectados ao que pretendem compreender.

Minha geração - sou de 1985 - nasceu sob o signo da "democratização" e foi acompanhada da ascensão do petismo e pela descrença quanto ao modo pelo qual o socialismo foi visto nos países que outrora estavam alinhados à União Soviética. Isto marcou profundamente o ambiente universitário, que tinha certo otimismo e confiança nas instituições, os quais hoje não parecem mais possíveis a curto prazo. No entanto, acredito que não seja exagero dizer que ainda estamos nesta mesma toada de certo modo. Infelizmente, não conseguimos enterrar os mortos e parece que continuamos procurando reavivar certa esquerda que abandonou o socialismo e que tem uma crença ingênua nas instituições ditas democráticas. A direita tomou consciência da crise que marca o sistema capitalista de produção e se radicaliza. A esquerda tenta dar sustentação a uma vertente de capitalismo que parece não ter mais como se colocar no curto prazo. E a vida universitária sobre a qual me perguntam, de modo mais ou menos mediado, coloca-se neste meio.

Sobre o primeiro elemento, mencionei o caráter tradicional da faculdade porque isto fascina muita gente, mas, ao mesmo tempo, gera uma relação um tanto quanto problemática com a instituição. Os professores da faculdade - bem como os alunos, para dizer a verdade - transpiravam certo orgulho confesso de se colocarem como representantes das “Arcadas”. Isto gerava certa identidade comum, mas também trazia 


\section{REVISTA ANGELUS NOVUS}

certo senso de hierarquia que levava a um afastamento considerável entre os alunos e os professores, dificultando a formação de laços autênticos de amizade entre os frequentadores do curso. O velho tradicionalismo de um curso de 1827 , e montado para fornecer burocratas e lideranças para um império escravocrata, de certo modo, está bastante vivo em um ambiente aparentemente aristocratizante. Digo aparentemente porque nunca tivemos sequer aristocracia no Brasil, moldado pela via colonial de entificação do capitalismo. As relações pessoais, nas "Arcadas”, oscilavam entre certo aristocratismo sem base social e um sentimento de que éramos, de um modo mais ou menos meandrado, agentes da modernização e da democratização do país. O fato de muitas figuras importantes da história brasileira terem se formado na "casa", tendo-se vários episódios marcantes passando por lá, levava a um reconhecimento comum alicerçado por uma identidade, para dizer o mínimo, problemática, que exalava o orgulho que mencionei. Trata-se de um ambiente em que o novo paga alto tributo ao velho, e parece não acreditar que aquilo de mais “arcaico” é um problema. Antes, o arcaico é tomado como a vantagem daqueles que parecem se colocar como uma espécie de intelligentsia livre à brasileira. Tal tradicionalismo, mesmo tendo certa comicidade, é bastante efetivo e não deixa de ter relevo no entendimento de um país como o Brasil.

A identidade intelectual que se formava por lá tinha certo requinte de megalomania e algum tom arrogante. $\mathrm{O}$ fato de a faculdade de Direito se localizar isolada do campus - tal qual em várias universidades, como a Universidade Federal de Minas Gerais (UFMG), por exemplo - fazia com que estas características, não raro, fossem acompanhadas de uma falta de diálogo com outras áreas do conhecimento, como a filosofia. E, assim, não era incomum certa visão um tanto quanto ensimesmada dos grandes problemas da época, bem como daquilo que passava pelo Direito. E aqui, novamente, este caráter sui generis, e decorrente da função que as faculdades de Direito exerciam em seu surgimento inicial no Brasil - principalmente ao olharmos para Recife e São Paulo -, é visto como uma força.

$\mathrm{O}$ isolamento, de certo modo, parece ser um sinal de superioridade e de senioridade. A sapiência do típico frequentador das “Arcadas”, porém, só rivalizava com seu diletantismo. Distante de debates qualificados sobre filosofia, letras, história, economia política, geografia etc., tal figura parece ser saudosa de bons tempos inexistentes ou de uma função dos intelectuais que, na melhor das hipóteses, deve-se ao caráter hipertardio do capitalismo brasileiro. Ao se falar de capitalismo hipertardio, vem-me à mente a crítica de José Chasin (1937-1998) ao integralismo, cujos principais expoentes eram Plínio Salgado (I895-1975), Gustavo Barroso (I888-1959) e Miguel Reale (1910-2006) - sendo este último considerado um grande filósofo do Direito das 
"Arcadas" e seu filho e seu sobrinho professores na faculdade, na área de Direito penal. Não cabe aqui discutir o rigor destas figuras da faculdade. Porém, mencioná-las é importante para que se perceba que grandes debates nacionais, com todas as suas adversidades, vicissitudes, e para o bem e para o mal, sempre passaram por lá.

Este ambiente foi central para minha formação pessoal, que - influenciada por algumas amizades, como de Gustavo Assano (mesmo ele sendo mais novo que eu), Marco Granieri, bem como por minha companheira à época, Ana Rüsche - rumou à tentativa de negar certas características vigentes no que eu enxergava como o típico "sanfranciscano". Eu via-me como alguém, de certo modo, fora do lugar naquela faculdade. Ao mesmo tempo, não conseguia deixar de pensar no esforço que precisei para estar lá. Refletia no seguinte sentido: de um modo ou de outro, eu precisaria - a duras penas, pois aquele clima não me agradava muito - achar um caminho alternativo. Tal caminho, desde o início, pareceu encontrar-se na pesquisa acadêmica. Nele, em minha cabeça, bastaria eu achar um professor com o qual eu pudesse ter uma boa relação que seria possível me exilar daquele ambiente intelectual tóxico, ao mesmo tempo em que eu poderia eventualmente trazer à tona estudos de relevo e cujo desenvolvimento me agradasse mais que a análise de textos jurídicos. Estes últimos, aliás, são modificados de tempos em tempos, o que faz com que, em grande parte, a formação dogmática do típico jurista envelheça rapidamente e se torne algo, no limite, sem base na própria realidade.

Já com dezoito anos, eu me considerava um marxista, tendo lido algumas obras do próprio Marx e havendo encontrado certo direcionamento no pensamento de José Chasin, que fora apresentado a mim por um veterano da faculdade chamado Adriano Blattner. Ele participava dos grupos de estudos organizados pelo professor Antonio Rago Filho, que viria a ser meu orientador de mestrado no futuro, na Pontifícia Universidade Católica de São Paulo (PUC-SP). Aquilo que eu pretendia estudar, assim, estava indubitavelmente no pensamento marxista. E isto eu havia percebido no primeiro ano de faculdade, em que conheci as pessoas que mencionei.

Em meio a tamanhas adversidades para a formação de uma crítica marxista, procurei referências na área. A faculdade de Direito da USP tinha como o principal expoente do marxismo o professor Alaôr Caffé Alves (1938-), que inicialmente me causou uma ótima impressão, mas de quem nunca consegui me aproximar, talvez, devido ao clima intelectual que mencionei e que, de um modo ou de outro, estava presente no referido professor devido à importância que sempre deu ao ambiente da faculdade. Li sua obra Direito e ideologia (1987), que me instigou bastante, mas que se distanciava da abordagem chasiniana, com a qual estava acostumado. Ao passo que a 


\section{REVISTA ANGELUS NOVUS}

análise de José Chasin procurava explicitar cada nexo e conexão da objetividade dos textos que analisava, e colocava para si uma tarefa aparentemente mais modesta - a compreensão da obra marxiana -, o professor Alaôr passava por autores que marcaram o marxismo do século XX para, então, trazer seu entendimento sobre o Direito, a ideologia, as relações materiais de produção, etc. Ou seja, aquele que, de modo um tanto quanto bairrista, eu tomava como o grande intelectual campo do Direito e marxismo no Brasil - somente um ano depois eu viria a tomar contato com a obra de Márcio Naves - trazia uma relação muito menos exegética com as formações ideais que analisava. Isto pareceu-me, de início, algo válido e necessário. Eu via esta empreitada como um passo em direção a uma postura antidogmática e relacionada à atualização de uma teoria originariamente desenvolvida no século XIX. Porém, quanto mais me aprofundava na obra de Marx com o auxílio da compreensão chasiniana, mais eu percebia que, em geral, embora não sempre, nem mesmo necessariamente, tentar ir além do autor de $O$ capital significava ficar aquém dele.

Para que fiquemos no que mencionei até agora, em geral, a ideologia era vista pelo professor Alaôr partindo de uma concepção sobre o caráter epistemologicamente errôneo da compreensão da realidade, na esteira da concepção de Marilena Chauí. Em Marx, por outro lado, como destacavam Lukács e Chasin, tal questão envolvia ao mesmo tempo as representaçóes - por vezes, mas nem sempre - invertidas do real e tinha como central o modo pelo qual as formas ideológicas tinham uma função concreta na realidade. Seria central, assim, ver também como se colocavam como formas a partir das quais os homens tomavam consciência das contradições sociais de uma época. Chasin, junto com Lukács, destacava muito este aspecto que citei e, assim, eu tendia a ver como essencial um cuidado a Chasin para que fosse possível uma análise séria do ser-propriamente-assim, ou seja, da conformação objetiva, bem como das determinações essenciais da sociedade. Ou seja, mesmo reconhecendo os méritos do professor Alaôr, distanciava-me de suas concepções sobre o marxismo e sobre a crítica marxista ao Direito.

Um próximo professor marxista foi Ruy Braga, que ao modo da Faculdade de Filosofia, Letras e Ciências Humanas (FFLCH) da USP, trazia a cada aula indicações de textos dos próprios autores que abordaria, bem como comentadores renomados.

Isto era muito diferente das aulas do professor Alaôr ou dos outros professores que eram endógenos à faculdade de Direito. Estes últimos nunca indicavam leituras prévias para as aulas, e muito menos leituras dos próprios autores que analisariam. No máximo, com exceção das leituras dos seminários de Introdução ao Direito e de Teoria Geral do Estado, tinha-se a indicação de um manual mais ou menos simplificado.

$6 \cdot$ ano XII, n. I7, 202I • ISSN 2179-5487 
Enxerguei no ímpeto do professor de sociologia - o Ruy - algo muito sério e honesto, de modo que conversar com ele trouxe-me indicações bibliográficas valiosas, bem como alguma noção sobre a necessidade de delimitar temas de pesquisa - algo que os estudantes de Direito quase sempre fazem de modo problemático. Cheguei, assim, à obra de Michael Löwy, que, em grande parte, utilizava Lucien Goldmann (1913-1970) como referência e criticava a obra do velho Lukács, que tanto influenciou Chasin e que vinha me fascinando. Li todos os livros que encontrei de Löwy. Encantei-me. Mas, tal qual ocorria com a obra de Goldmann, como eu viria a perceber depois, tinha-se certas analogias e afinidades eletivas - a questão da homologia estrutural, ou seja, do paralelismo entre estruturas diferentes, mas com funcionamentos correlatos, essencial a estes pensadores, coloca-se aqui - que pareciam saltos para mim. E, deste modo, em um momento em que a obra de István Mészáros (1930-2017), Para além do capital (1995), era muito debatida, decidi voltar-me à obra de Lukács com mais cuidado. Acreditava que precisava de um solo sólido para me assentar.

Esses primeiros impulsos teóricos foram muito importantes para mim. Combinado às amizades e às pessoas que marcavam meu desenvolvimento, eles trouxeram certa postura questionadora e voltada ao rigor teórico, que era absolutamente alheio ao típico "sanfranciscano", bem como ao ambiente intelectual da faculdade. Ou seja, eu estava encontrando um caminho que gostaria de percorrer. Mas Ruy Braga era da faculdade de sociologia e Alaôr Caffe Alves, aos meus olhos da época, parecia enxergar os alunos interessados como demasiado ingênuos e crus para uma conversa - e uma eventual orientação de pesquisa - sobre marxismo. Meu primeiro ano de faculdade terminava com estas impressões, que me levavam a testar se realmente deveria permanecer na faculdade.

Neste momento, comecei a procurar entender como se colocava o Direito na prática e estagiei em um grande escritório durante seis meses no começo do segundo ano do curso. Não é necessário dizer que, com minhas convicções teóricas, e com a personalidade que já trazia certa ojeriza, não só diante dos frequentadores das "Arcadas", mas às características que marcam, em geral, os juristas, tudo foi desastroso. Neste momento, conheci o professor Sérgio Resende de Barros, recém-confesso marxista - algo bastante peculiar para um professor em final de carreira -, que trouxe certa abertura para minhas pretensões e aceitou orientar-me. Sua formação era no Direito constitucional e estava encantado com a recém-publicação dos Cadernos do cárcere, 5 de Antonio Gramsci (I89I-I937).

5 Trata-se da tradução da editora Civilização Brasileira, que teve seu primeiro volume publicado em I999. Os Cadernos do cárcere foram redigidos por Gramsci entre 1929 -1935 e publicados pela primeira vez entre 1948 I95I. Uma edição crítica somente veio à luz nos anos 1970 pela editora italiana Einaudi. No Brasil, a obra de 


\section{REVISTA ANGELUS NOVUS}

Li e discuti com o "Serjão" sobre Gramsci, mas já trazendo à discussão muito de Lukács e o recém-descoberto Mészáros. Nossos debates, porém, passavam muito mais por cervejas e frango assado no "bar do curintiano" do que pela formalização de uma pesquisa acadêmica. Ele sempre pretendia me trazer para o campo da teoria do Estado e do Direito público, dizendo explicitamente que eu precisaria de um emprego para financiar minhas pesquisas, dado que, na época - 2005 - as bolsas de estudos para graduação e para a pós-graduação, em seu juízo, eram baixas e escassas. Nossas conversas passavam também por certo aconselhamento profissional, ao qual vim a acatar.

Em 2006, em meio terceiro ano do curso, já era funcionário público, trabalhando de técnico administrativo na Caixa Econômica Federal - em que permaneci até conseguir uma bolsa de mestrado em 2009. Serjão era uma pessoa próxima, com quem eu conversava muito sobre marxismo, sobre a vida e sobre a realidade da sociedade capitalista e do Direito da época. Porém, acabou não sendo um orientador. De um lado, porque não levava jeito para a burocracia envolvida na formalização de pesquisas de alunos de graduação. Doutro, porque estava fincado no campo do Direito público e da Teoria do Estado. Sua abordagem procurava distanciar-se daquela do jurista, mas sempre reiterava a necessidade de se voltar ao terreno do Direito. De um modo muito diferente do professor Alaôr, também enxergava o ambiente da faculdade de Direito, bem como dos juristas, como um campo privilegiado de atuação. $E$ isto não deixava de me incomodar.

Foi então que conheci a professora Jeannette Maman, a partir da participação em suas aulas de pós-graduação - que me foram indicadas por Ana Rüsche. Sua postura era completamente diferente daquela dos demais professores da faculdade. Achava ótimo que alunos da graduação, como eu, frequentassem suas aulas. Também procurava uma leitura atenta dos textos dos grandes autores. Ao descobrir que eu me identificava como marxista, achou interessantíssimo e apontou proximidades entre a abordagem heideggeriana da inautenticidade e da perda de si e o estranhamento marxista, tema este que eu viria a desenvolver em meu doutoramento a partir do embate entre Heidegger e Lukács.

Ela, como não poderia deixar de ser com uma heideggeriana séria, indicou-me a leitura da obra de Martin Heidegger (I889-1976). E, mais tarde, do jovem Herbert Marcuse (I898-1979), que havia sido orientado pelo autor de Ser e tempo (1927). No que

Gramsci passou a ser traduzida e publicada nos anos 1960. Porém, os Cadernos somente receberam suas primeiras traduções no fim dos anos 1990 e início dos anos 2000 (Cf. DEL ROIO, Marcos. Resenha de: GRAMSCI, Antonio. Cadernos do Cárcere. Rio de Janeiro: Civilização Brasileira, 1999, 496 p. Crítica Marxista, v. I, n. II, 2000, p. 135-138. Disponível em: «https://www.ifch.unicamp.br/criticamarxista/arquivos_biblioteca/resenhas8Resenhaz.pdf»). $\quad(\mathrm{N} . \quad \mathrm{da}$ RAN)

$8 \cdot$ ano XII, n. 17, 202I • ISSN 2179-5487 
não tardei a começar o duro estudo destes autores, com o aprofundamento - sempre necessário - na obra de György Lukács (I885-197I), em especial na Ontologia do ser social (obra lukacsiana cuja publicação na íntegra é póstuma). Jeannette sempre era muito atenta a cada aluno e procurava dialogar com todos eles, mesmo parecendo ser um pouco dura - embora sempre justa - em seus desacordos. Isto sempre tinha como referência os textos que estavam sendo discutidos em cada encontro. Textos estes que, em seu curso sobre Heidegger, referiam-se à obra magna de Heidegger mas sempre remetiam à Carta sobre o bumanismo (1947). A mim, aquilo tudo era extremamente proveitoso. Eu colocava meu marxismo à prova e fazia com que meus eventuais posicionamentos sobre Martin Heidegger precisassem sempre ser fundamentados com cuidado. No mais, tratava-se de textos aos quais Lukács fazia referência em Marxismo ou existencialismo (1948), Heidegger redivivus (1948) e na Ontologia - só para que citemos as principais e mais sistemáticas críticas de Lukács. Ou seja, de certo modo, o que viria a se tornar a primeira parte de minha tese de doutoramento - a segunda, ainda não publicada, é sobre a crítica lukacsiana ao Direito em meio ao capitalismo manipulatório - estava sendo gestada desde o terceiro ano de meu curso. A leitura de um autor difícil e sofisticado como Heidegger foi essencial a mim. Os grandes problemas da filosofia do século XX estavam todos neste autor que, sempre perspicaz, posicionava-se sobre eles. E, sendo suas posições diferentes daquelas de Lukács, eu percebia a unidade indissociável entre os posicionamentos mais basilares destas duas distintas ontologias e os posicionamentos acerca de uma questão essencial: que fazer?

Como professora de pós-graduação, Jeannette, e depois Antonio Rago Filho, foram grandes exemplos para mim. Frequentei os cursos de pós-graduação da professora durante o restante de minha graduação, bem como durante a pós-graduação - o doutorado, no caso. Tornei-me também, na graduação, seu monitor nas matérias a ela atribuídas na grade horária da graduação. Ou seja, eu finalmente havia encontrado uma orientadora. Sua personalidade franca e direta não fazia o tipo daquele ambiente intelectual marcado pela pose e pela vaidade. Sua seriedade com os textos era diretamente proporcional à sua abertura diante dos alunos que ela julgava interessados e atentos. E, deste modo, começamos uma relação duradoura, que, formalmente - hoje a tenho como uma amiga -, foi até o fim de meu doutorado, em 2013. O processo de orientação foi tranquilo e proveitoso, com muitos embates sobre a compreensão da obra de Heidegger e com o incentivo de fazer matérias fora da faculdade de Direito frequentei [na FFLCH-USP], por exemplo, os cursos de Jorge Grespan e Lincoln Secco, na história, Vladmir Safatle, na filosofia, e Anselmo Alfredo, na geografia. Destes, acabei por manter contato com o Jorge, que foi bastante importante em meus 


\section{REVISTA ANGELUS NOVUS}

estudos - inclusive os mais recentes - sobre o Livro III de O capital (I894). Em se tratando de formação, porém, as figuras centrais foram sem dúvida Rago e Ester Vaisman. Porém, para tratar deles, escaparíamos demais do tema da pergunta. Mais diretamente sobre ela, eu diria que tive muita sorte em meus debates com a professora Jeannette, que sempre foi muito transparente, e nunca deixou de colocar suas desavenças de modo claro e honesto.

Eu acreditava, e ainda acredito, que esta posição carente de ilusões e que não deixa de criticar aquilo que precisa ser criticado seria correta. Sem ela, ficaríamos presos aos erros do passado, tal qual acontecia com a esquerda da época, e acontece ainda hoje.

\section{WS E HC}

Seu livro, Ontologia nos extremos: o embate Heidegger e Lukács, uma introdução, publicado em 2019, é um desdobramento de seu doutorado. As posições contrapostas entre ambos os autores, de algum modo tem um embate também político ou conjuntural?

\section{VBS}

O livro é uma versão modificada da primeira parte - mais "filosófica”, por assim dizer - de meu doutorado, ${ }^{6}$ como mencionei. Ele é motivado pela posição segundo a qual "não há visão de mundo inocente”. Isto foi trazido por Lukács explicitamente em $A$ destruição da razão (1954), obra injustamente renegada por muitos autores e somente traduzida recentemente no Brasil. De acordo com Lukács, trata-se de apreender a gênese, a estrutura e a função de uma formação ideal. Esta última não poderia simplesmente ser interpretada como bem se entendesse. Tratar-se-ia de explicitar a objetividade de um pensamento em seu ser-propriamente-assim, trazendo-se as determinações deste a partir do próprio texto.

Posteriormente, José Chasin desenvolveu isso no que chamou de análise imanente. Ou seja, certamente tem-se a dimensão política como algo essencial às formações ideais que são colocadas diante de nós. Porém, não se pode reduzir ontologias sofisticadas e importantes, como aquelas dos dois autores, às suas posições políticas imediatas. A estrutura de seus pensamentos, bem como a gênese destes, precisam ser vistos ao passo que a função concreta e o posicionamento dos autores vêm à tona de modo cuidadoso.

6 Trata-se de Ontologia, técnica e alienação: para uma crítica ao direito, defendida em 2or3. Disponível em: «https://www.teses.usp.br/teses/disponiveis/2/2139/tde-I3022014-I44931/pt-br.php». (N. da RAN)

Io $\bullet$ ano XII, n. I7, 202I • ISSN 2I79-5487 
Para que se diga com todas as letras: de um lado, não é possível fazer uma exegese ou uma análise estrutural que considere os textos como algo fechado sobre si mesmo, autônomos em um sentido absoluto. Doutro lado, não há como trazer uma determinação social do pensamento ao desconsiderar a arquitetura interna, bem como as categorias específicas que caracterizam uma formação ideal. No primeiro procedimento, se fetichiza o texto de modo dogmático. No segundo, em verdade, desconsidera-o. Ele aparece como um mero detalhe, ou como um incentivo para divagações mais ou menos competentes. A apreensão da objetividade do texto torna-se imputação de sentido.

E, é preciso ressaltar que a crítica imanente marxista não se confunde com qualquer destes dois modos de apreensão do real. Em verdade, ela ataca estes posicionamentos unilaterais. O primeiro é visto como tipicamente idealista. O segundo, traz a marca de uma espécie de manipulação, muito presente no neopositivismo criticado por Lukács em sua Ontologia e, eu arriscaria colocar, no pós-estruturalismo de hoje.

Para a crítica marxista, as dimensões da gênese, da estrutura e da função estão interligadas e precisam ser vistas conjuntamente. Não se trata nem de negar a determinação social - que é essencial a qualquer marxista - nem de enxergá-la sem as devidas mediações. Assim, não deixa de ser irônico o fato de os críticos contemporâneos do marxismo - ligados a versões mais ou menos inspiradas no pós-estruturalismo incorrerem, não raro, na falta de mediações que atribuem ao pensamento de Marx e de seus seguidores. Ou seja, a crítica ao suposto mecanicismo do marxismo aparece, não com a explicitação dos nexos presentes na obra do próprio Marx, mas com imputações ao autor. Vê-se, por exemplo, o autor como incapaz de apreender a complexidade das relações sociais não econômicas devido ao seu "eurocentrismo" e ao "economicismo" atribuídos, em geral, aos homens do século XIX. Em vez de se provar qualquer coisa, pressupõe-se aquilo que precisaria ser mostrado, explicitado e, se possível, contestado.

Destaco estes aspectos "metodológicos" porque o cuidado no tratamento das formações ideais sempre é necessário. Mesmo sabendo, post festum, qual a posição política de determinado autor, não se pode simplesmente reduzir seu pensamento a ela.

Somente para que usemos um exemplo extremo, podemos dizer que muito embora Heidegger tenha, nos anos de 1933 a 1935, visto com bons olhos o nazismo, sua obra não é a típica expressão deste movimento político. Embora, de modo distinto, também não podemos dizer que por Lukács destacar o papel da União Soviética stalinista na Segunda Guerra Mundial (1939-1945) e contra a difusão do nazifascismo, ele se torna um stalinista. Sobre este último aspecto, não me deterei aqui. Porém, 


\section{REVISTA ANGELUS NOVUS}

gostaria de apontar como se apresenta esta questão, tão difícil, no autor de Ser e tempo. Abordo isto no livro, mas ressalto que um estudo cuidadoso é necessário após a publicação dos chamados Cadernos negros do autor, cuja publicação só se deu recentemente, em 20I4. E, infelizmente, ainda não pude realizar esta tarefa, a qual julgo ser de grande relevo para a filosofia, até mesmo porque o debate sobre as posiçóes de Martin Heidegger foi muito intenso no século XX.

Voltemos ao pensamento heideggeriano e à sua posição diante do nazismo.

As mediações de tal posicionamento do autor precisam ser vistas com cuidado, sob risco de se cair em alguma das duas posturas equivocadas destacadas. E, em verdade, a problematização, por assim dizer "metodológica”, deste aspecto não deixa de ser essencial à Ontologia, de Lukács. Acredito que o marxista húngaro seja capaz de conseguir lidar com o estatuto das formações ideais de modo muito mais interessante, cuidadoso e rigoroso que os filósofos burgueses e que a maioria dos marxistas. A sua crítica a Heidegger, bem como ao irracionalismo - que iria, no limite, de Schelling a Hitler, no caso da Alemanha de sua época, para que se use a dicção de $A$ destruição da razão - procura ser livre destas unilateralidades intoleráveis a um pensador sério. A análise lukacsiana de Heidegger, porém, não chega a esgotar os temas do autor, nem mesmo a estrutura interna de sua obra. Ou seja, tem-se um ponto de partida a ser analisado com cuidado, mas o autor não deixou um estudo sistemático sobre o tema.

Acredito que, na Ontologia, mas também em Heidegger redivivus, sua posição esteja, no essencial, correta. Porém, há alguns aspectos não tratados por Lukács que precisam ser trazidos à tona e que destaquei no livro, remetendo, dentre outras, às noções de acontecimento, técnica e metafísica, centrais à conformação do pensamento heideggeriano e de grande relevo na constituição, e posterior negação, daquilo que chama de ontologia fundamental. Somente compreendendo a sua ontologia podemos entender seu posicionamento; e apenas enxergando a crítica que realiza a ela é que vemos como que, em um momento posterior, o autor vem a mudar de posicionamento sobre o tema.

Agora, portanto, coloco-me a tratar diretamente de um tema delicado, o nazismo.

Primeiramente, gostaria de destacar que a postura bastante avessa à "técnica da máquina” por parte de Heidegger é, em verdade, incompatível com as determinações essenciais do "modernismo reacionário", típico da concepção nazista, para que utilizemos a dicção do excelente livro de Jeffrey Herf, Modernismo reacionário (1993). Se o pensamento nazista vem a trazer certo elogio da técnica, ligado, inclusive, ao incentivo à industrialização e à militarização, neste aspecto, ele é oposto ao heideggeriano. No entanto, é preciso deixar claro: não há como desconsiderar que, 
segundo o autor de $O$ que é metafísica (1929), justamente teria sido o nacionalsocialismo a compreender a grandeza do acontecimento caracterizada no "encontro da técnica determinada planetariamente com o homem moderno”.

Ou seja, o nível em que Heidegger coloca a questão, é outro: ele enxerga o nazismo como algo condizente com o evento e o acontecimento que marca uma época, e que seria capaz de salvar o ser-aí alemão em uma espécie de terceira via diante dos Estados Unidos e da União Soviética. Mas isto é feito para salvaguardar a "grandeza” de um "povo metafísico", e não em nome da terra, da raça e do sangue. A fundamentação da posição heideggeriana é bastante sui generis, e não faz sentido fora de sua ontologia fundamental. Porém, leva a enxergar no nacional-socialismo algo que toca a historicidade do presente de modo profundo, trazendo consigo tanto o perigo quanto aquilo que poderia salvar o ser-aí ocidental. A abertura para o novo teria esta natureza avessa ao cálculo e à ratio (expressão latina utilizada para se remeter à razão), tratando-se de um acontecimento. E, segundo o autor, no caso, haveria um acontecimento dotado de grandeza, aquela que poderia, no limite, salvar o ser-aí ocidental.

A função social da ontologia heideggeriana leva a esta correlação com o ocidente, bem como com certa ênfase no povo alemão, visto como metafísico. (Destaco aqui o caráter positivo do termo neste momento, colocando-se como algo importante.)

Há certa ênfase na Alemanha. Ela não estaria no mesmo nível de desenvolvimento dos Estados Unidos e da União Soviética. Segundo Lukács, as condições do atraso alemão, assim, não tomadas como medida pelo autor alemão. E, assim, podemos dizer que, se o apego às vicissitudes da miséria alemã está presente tanto na posição nazista quanto na heideggeriana, é preciso que se diga que isto se dá, sob certos aspectos, de modo diametralmente oposto. De um lado, no nacional-socialismo, tem-se a busca pela radicalização da técnica da máquina, doutro, a busca por uma concepção originária de techné, que se coloque contrária à perda de si e ao estranhamento. A techné, como diz o autor nas conferências de 1936 publicadas em Origem da obra de arte (1950), remeteria a uma forma de poiesis e, portanto, em sua concepção originária - que precisaria ser recuperada. Heidegger opõem-se ao modo pelo qual a prática do homem moderno se organiza, com a perda de si, com o estranhamento, com a reificação; e, como sabem, são estas temáticas caras ao marxismo. E, com a tematização do cotidiano, são pontos centrais da obra lukacsiana - e, verdade, em toda a sua extensão - e ao pensamento heideggeriano.

Heidegger, portanto, tece uma crítica - segundo Herf, reacionária - à práxis do homem moderno que vive na sociedade capitalista. Ele critica a própria modernidade, ao mesmo tempo em que sabe que não pode ser colocar fora da historicidade. E o 


\section{REVISTA ANGELUS NOVUS}

nazismo é justamente - como ele viria a reconhecer posteriormente - uma expressão desta mesma modernidade. $\mathrm{O}$ modo como o autor coloca isto certamente precisa ser questionado, com atenção e cuidado aos meandros de sua obra. Em um primeiro momento, o autor alemão vê o nazismo como algo que poderia trazer a abertura diante da inautenticidade do presente marcado pela técnica da máquina; depois, deixa de enxergar neste movimento uma solução e traz posicionamentos, no mínimo, questionáveis: o trator da agricultura moderna e a câmera de gás, usados como exemplo pelo autor, podem até expressar o que ele chama técnica e que vem a remeter a uma atitude agressiva diante da natureza e dos entes. Porém, a colocação da questão desta maneira eclipsa justamente o essencial à compreensão da história. As forças produtivas, bem como as relações de produção que dão solo à técnica são frutos do processo unitário que se desenvolve tendo por solo as relações materiais de produção. Se não se destaca isto, como aponta Lukács, qualquer atribuição de importância à dimensão histórica - que é muito frequente em Heidegger na figura da historicidade - vem a ser meramente verbal.

Ou seja, as colocações heideggerianas sobre os acontecimentos são indissociáveis de sua ontologia e, em verdade, de sua concepção sobre a história e a historicidade.

Para Lukács, em verdade, trata-se de compreender, para que remetamos a Marx, um conjunto de relações sociais, e não coisas, ou a dimensão originária da noção de coisa, que remeteria a certo "habitar" - como diz o autor de Ser e tempo em um de seus ensaios. Com sua noção de derrelição, de estar-lançado, o autor da ontologia fundamental pensa a historicidade de modo extremamente perspicaz - o que encanta Marcuse por algum tempo, por exemplo -, mas é incapaz de apreender concretamente a gênese histórica do presente, e, portanto, as possibilidades atuais nele. É forçado a apelar a uma dimensão mais originária da técnica, que se colocaria no pensamento présocrático e que levaria, não à práxis consciente e à transformação das condições materiais de existência dos indivíduos, mas à poeisis que se colocasse de modo autêntico em duas situações: na origem das obras de arte e na fundação de Estados. $\mathrm{O}$ ímpeto de Heidegger em seu apoio ao nazismo, portanto, não é aquele de um modernismo reacionário, mas de uma postura, prima facie, contrária à modernidade. Trata-se, assim, de uma espécie de anticapitalismo romântico de um modo muito mais coerente do que se tem na visão de mundo nazista. E esta postura é bastante coerente com o seu desenvolvimento de uma ontologia fundamental, com uma concepção de ser que, embora dialogue com aspectos da teologia, leva aos pré-socráticos.

A categoria do "acontecimento", por sua vez, relaciona-se à própria concepção de verdade como alethea, como desvelamento, presente no autor, e central a toda a sua

$\mathrm{I}_{4} \bullet$ ano XII, n. I7, 202I $\bullet$ ISSN 2I79-5487 
obra. Esta concepção, por seu turno, coloca-se tanto na crítica à ratio moderna marcada pela noção de verdade como adequação entre sujeito e objeto - quanto à razão como colocada tipicamente na filosofia clássica alemã. Se o irracionalismo nazista pode trazer o primeiro aspecto, mesmo que de um modo tosco, o segundo, em verdade, não está presente, de modo algum, nele. E, com isto, talvez Heidegger traga uma fundamentação muito mais sofisticada ao Füher que os nazistas em determinado momento. Porém, isto não faz de sua teoria algo simplesmente subsumível ao nacionalsocialismo. E destacar isto é essencial. A filosofia heideggeriana trata com atenção problemas essenciais à sociedade capitalista, admite diversos problemas desta e suas soluções são engenhosas. Digo isto porque o autor, acredito, merece ser estudado com seriedade e é uma tarefa dura, mas necessária, contrapor-se a ele de modo marxista, como procurou demonstrar Lukács na Ontologia.

Sobre a ontologia heidegeriana diante do nazismo: ela se encontra com ele em determinado momento, não há como negar. Heidegger, como colocado em carta a Marcuse, inclusive, nunca se arrepende de seu posicionamento pretérito. $\mathrm{O}$ autor de Ser e tempo procura enxergá-lo em sua historicidade e, com isto, traz certa equiparação - a meu ver absurda - entre o nacional-socialismo e o stalinismo - equiparação esta que seria, de certo modo, trazida por Hannah Arendt (1906-1975) posteriormente - que, de um modo meandrado, de acordo com Heidegger, estaria presente ainda na concepção de Marcuse. (Não preciso dizer que também acredito que esta colocação do autor de Ser e tempo seja igualmente absurda.) Ou seja, não se trata de criticar a posição de Heidegger simplesmente. A priori, parece bastante simples e correto condenar alguém que apoiou um regime como este durante um tempo não negligenciável. E, de certo modo, é. Porém, trata-se de ver como que tal apoio não é simplesmente contingente à filosofia do autor. (Destaco este “como”.) Dizer que a posição de um autor é inseparável de quem ele realmente é pode ser necessário, mas não deixa de ser quase que tautológico para um marxista. Ou seja, isto é insuficiente. Não basta declarar a determinação social do pensamento. Trata-se de enxergar a maneira pela qual a estrutura interna deste tem uma gênese e leva a determinada função social.

E isto, no autor de Ser e tempo, passa pela crítica ao estranhamento. E, sobre este aspecto, Lukács se debruçou, tanto em $A$ destruição da razão, quanto na Ontologia. As ontologias de Lukács e de Heidegger, portanto, são distintas, não só devido aos seus diferentes posicionamentos quanto à categoria ser, mas porque tais posicionamentos estão coordenados de modo coerente com o restante do pensamento dos autores, também, no que diz respeito à dimensão da efetividade de seus pensamentos. O livro que escrevi - Ontologia nos extremos: o embate Heidegger e Lukács, uma introdução 
(2019) - procura demonstrar que tratar de ontologia não é algo que se volta somente aos filósofos profissionais, que, imbuídos de um ímpeto exegético, procuram situar os distintos pensadores na história do pensamento. Ao trazer à tona o embate das ontologias do autor da Ontologia do ser social e do autor de Ser e tempo, um tema essencial, por exemplo, é a conformação da esfera pública da sociedade civil-burguesa. E, em ambos os autores, o fenômeno do estranhamento é essencial ao se tratar desta e da cotidianidade presente nela.

Lukács aponta que a descrição heideggeriana do impessoal, que trata justamente do cotidiano da sociedade capitalista - embora o autor alemão não coloque a questão nestes termos - é uma das razões principais do sucesso da obra de Heidegger. De modo correto, enxerga-se no cotidiano certa unidade marcada por uma obviedade que não se sabe de onde vem. Ter-se-ia a perda de si, em que o mundo apareceria de modo reificado e estranhado. Para o autor da Ontologia, a descrição heideggeriana da coisa é bastante correta. Porém, em meio à noção de historicidade do autor, haveria diversos problemas. Em vez de Heidegger procurar o fundamento das potências estranhadas que analisa no modo pelo qual, ao fim, os indivíduos fazem a si mesmos, também no cotidiano, o autor alemão não vê como realizar isto sem cair nas mesmas obviedades que critica. Ou seja, em Heidegger, aparece como algo vedado a compreensão racional das condições de vida dos indivíduos. Tal ímpeto seria aquele de um racionalismo inaceitável e, assim, acabar-se-ia perdendo-se inelutavelmente na cotidianidade, de modo que somente a angústia poderia trazer uma abertura diante desta situação desesperadora. Heidegger, portanto, vê tal angústia como parte do desvelamento da historicidade. Somente por meio dela, em Ser e tempo, ter-se-ia a abertura ao acontecimento colocado de modo autêntico. E, devemos destacar: segundo Lukács, justamente esta disposição afetiva, contrária à razão, e marcada pelo desespero, é uma base sem a qual o irracionalismo nacional-socialista não existe.

Ou seja, há também uma correlação necessária entre as disposições afetivas que estão presentes na ontologia heideggeriana e sua posição diante do nazismo. Mas todas as ressalvas colocadas acima precisam ser levadas em conta. E, sobre o assunto, por fim, é interessante ver como um tema essencial à filosofia, aquele da metafísica, muda de tom em Heidegger justamente com sua mudança de posição diante do nazismo: se, de i929 a meados da década de 1930 - mais precisamente 1934-1935 -, o autor traz a noção de metafísica, por vezes, de modo elogioso, depois de suas prelações sobre Nietzsche autor muito caro aos nazistas -, a tônica é totalmente outra: o autor de Vontade de poder, ou Vontade de potência (I90I), se preferirem, é visto - acompanhado de Marx, acrescenta Heidegger posteriormente - como o ápice da metafísica ocidental. Esta, por

I6 - ano XII, n. I7, 202I • ISSN 2179-5487 
sua vez, é enxergada como agressiva, impassível e marcada pela técnica, no limite, pela técnica da máquina. Ou seja, as características que Heidegger criticava nos Estados Unidos e na União Soviética, e que fizeram com que ele elogiasse a Alemanha como algo distinto e como marcada pelo povo metafísico, agora, são atribuídas à própria metafísica ocidental. Ela passa a ser o grande inimigo do autor alemão. Nela, ele enxerga tanto Nietzsche quanto Marx, tanto a câmara de gás quanto o trator agrícola. E, assim, há de se perceber como que a virada, ou a viragem heideggeriana - uma temática central àqueles que estudam o pensamento do autor - não deixa de ter uma correlação íntima com a posição política de Martin Heidegger. A gênese, a estrutura e a função da formação ideal, assim, precisam ser enxergadas em sua complexidade, e não de modo redutor.

A política, portanto, é essencial para que compreendamos o pensamento de Heidegger, mas todos os cuidados mencionados são necessários para que não incorramos em posicionamentos rasteiros e descuidados. A crítica imanente lukacsiana tem isso por central, e remete ao posicionamento segundo o qual uma posição socialista precisa entender, não as caricaturas que são feitas de determinado momento ou de determinado pensamento, mas o ser-propriamente-assim. Lukács combate Heidegger, não só pela posição política deste, ou à influência do pensamento do autor de Ser e tempo, mas porque questões essenciais ao desenvolvimento filosófico do século $\mathrm{XX}$ estão presentes no pensamento do autor. Trata-se, assim, de uma defesa do socialismo e do marxismo.

\section{WS E HC}

No que se diz respeito à filosofia contemporânea, em especial à metafísica e à ontologia, Marx é “reduzido” à sociologia, ou uma passagem do pensamento político. No caso de Lukács, percebe-se que a ontologia é negligenciada, tendo como baluarte do estudo dessa temática, o pensamento de Heidegger e a fenomenologia francesa. Em sua visão, por que há essa certa lateralização da ontologia lukácsiana? Seu livro pretende, de alguma forma, trazer esse debate?

\section{VBS}

Sinceramente, não é de se assustar que um pensador marxista sério seja negligenciado. Isto, de certo modo, sempre ocorreu. E, acredito, continuará a acontecer enquanto os pensadores balizados pelo pensamento de Marx trouxerem uma posição 


\section{REVISTA ANGELUS NOVUS}

concreta bem clara no sentido da necessidade da crítica ao modo de produção capitalista.

Precisamos, porém, abordar algumas dimensões importantes do que perguntam.

Primeiro, ao filósofo profissional, "misturar" estas coisas - ontologia, categorias da filosofia clássica alemã, trabalho, política, relações econômicas, etc. - a Lukács parece trazer consequências desastrosas ao pensamento realmente filosófico. De um lado, temse uma abordagem filosófica mais tradicional e exegética, que enxerga nosso autor como alguém que incomoda demais por levantar a questão da determinação social do pensamento, e da ação dos indivíduos. Doutro, coloca-se certa filosofia, pretensamente iconoclasta e progressista, que vê o ímpeto lukacsiano de embate com categorias centrais à filosofia clássica alemã, bem como com pensadores como Heidegger, Nicolai Hartmann (I882-1950) e Ernst Bloch (I885-1977), como algo demasiadamente conservador. Em linhas gerais, segundo estes pensadores supostamente revolucionários - e desculpo-me aqui por não poder tratar da questão com o cuidado necessário tratar-se-ia, em verdade, de trazer novas interpretaçôes, com potência ativa mais imediata no mundo atual. Ou seja, aqui, tem-se sob outro ângulo, algo que já apareceu quando tratamos da análise imanente, da gênese, da estrutura e da função das formações ideais: se quiserem assim colocar, trata-se de algo que gira em torno do modo de proceder de Lukács diante das formas ideais e do ser-propriamente-assim da realidade. Alguns diriam se tratar de diferenças essencialmente metodológicas. Mas, acredito não ser exatamente este o caso, pois o que está em jogo não é somente o estatuto acertado de uma teoria do conhecimento. Trata-se essencialmente de um modo de se colocar se posicionar diante da sociedade e da realidade efetiva.

Há um outro aspecto intimamente correlacionado ao que acabei de trazer acima.

Mesmo autores relacionados a certa crítica à sociedade capitalista, e a uma linhagem de crítica ao presente, autores estes muito lidos e aclamados hoje em dia, como Jürgen Habermas (1929-) e Michel Foucault (1926-1984), possuem um ímpeto que destaca de modo exacerbado a importância das mediações cognitivas, no limite, na própria constituição do mundo. No último autor, isto acontece passando por certa leitura de Nietzsche e da vontade de poder e no primeiro, ao menos depois de sua guinada linguística, isto se dá debatendo muito com filosofias que têm por central a linguagem, os atos de fala, os sinais etc. Não entrarei nos detalhes destas posições, que são sofisticadas e que, tal qual o pensamento de Heidegger, merecem um estudo cuidadoso por parte dos marxistas. Porém, sinto-me obrigado a destacar que no caso de ambos os autores, como em tantos outros, ao tentar escapar da unilateralidade de certo

I8 • ano XII, n. I7, 202I • ISSN 2I79-5487 
marxismo - para que sejamos claros, do marxismo vulgar, que realmente precisa ser criticado - vai-se em direção a uma concepção que não deixa de ser idealista.

Nestes autores, a negação da autarquia da realidade objetiva e o apego às formas mais imediatas pelas quais esta realidade aparece à consciência a partir da dificuldade de entrelaçar as formas de representação às formas materiais do mundo, leva a certa crítica à própria noção de razão. Se em Hegel, e em Marx, as dificuldades do entendimento levavam à razão e à compreensão do processo histórico que leva ao presente, aqui, parece que justamente neste passo dos dois autores dialéticos mencionados reside o equívoco daquilo que Habermas chamou de discurso filosófico da modernidade. De um lado, com a arqueologia do saber foucaultiana, isto se dá radicalizando alguns aspectos da teoria nietzschiana e da correlação entre saber e poder. Doutro, com a teoria da ação comunicativa, isto ocorre radicalizando a crítica dos frankfurtianos à razão. E gostaria de destacar um ponto neste momento: se para os últimos a aporia da crítica estaria em que somente seria possível criticar a razão a partir da própria razão, para Habermas, há a necessidade de uma nova forma de razão, a comunicativa, que, em verdade, deixa de lado grande parte das pretensões da filosofia e da práxis política pregressas. Digo tudo isto porque a pretensão da ontologia lukacsiana é aquela de apreender o ser-propriamente-assim do real. E é justamente isto que é deixado de lado, como base destas importantes filosofias da atualidade. Nelas, neste sentido e falando em termos de Lukács, tem-se uma pretensão absolutamente anti-ontológica. A crítica à noção de verdade como adequação - e aí há uma correlação bastante clara entre estes autores a posição heideggeriana -, em minha opinião, e passando pelos pontos de partida destes autores, leva-os ao idealismo.

Mesmo no caso em que a noção de razão não é nominalmente abandonada, estamos bastante afastados de algo que prima pela autarquia da realidade objetiva. Coloca-se certa correlação entre linguagem, entendimento e interação como aquilo que constitui o próprio mundo - aqui há a influência de Husserl, mas não poderia tratar deste tema. A realidade objetiva se torna algo tão longínquo quanto a coisa-em-si kantiana neste passo que Habermas dá em direção a Kant e contra as filosofias de Hegel e de Marx. Este passo bastante comum, como demonstrou Lukács em $A$ destruição da razão, traz consequências bastante grandes para a filosofia: acaba-se por rumar a uma espécie de idealismo subjetivo. E eu diria que esta disposição da filosofia contemporânea é absolutamente avessa a uma teoria como a de György Lukács. Assim, eu gostaria de pontuar que uma das razões para a ontologia lukacsiana não ser estuda e valorizada passa por isto. 


\section{REVISTA ANGELUS NOVUS}

Lukács, assim como a maioria dos marxistas, acaba por ser reduzido a um autor menor, seja da sociologia, seja da teoria política. Ou seja, se nosso autor veio justamente a mostrar como que as ciências parcelares são o resultado da decadência da teoria burguesa, acaba-se por colocá-lo justamente neste campo, de modo, no mínimo, descuidado. Desconsidera-se grande parte do embate do autor da Ontologia. Em parte, isto ocorre devido às questões que procurei levantar acima. Porém, não há como negar que há também uma dose considerável de má-fé. A literatura que demonstra que o marxismo possui abordagens riquíssimas sobre temas, por assim dizer, filosóficos é vasta. Mesmo os mencionados frankfurtianos, com Max Horkheimer (I895-1973), Herbert Marcuse (1898-1979) e Theodor Adorno (1903-1969) são leituras obrigatórias sobre a filosofia alemã dos séculos XIX e XX. Lukács também tem abordagens sobre diversos filósofos, desde as suas obras juvenis. No campo da estética, os mesmos autores mencionados - conjuntamente com nosso autor - deveriam ser referências obrigatórias. Mas, como sabemos, isto passa longe de ocorrer.

Porém, a questão que colocam, possui ainda uma dimensão que caracteriza muito o pensamento filosófico contemporâneo noutra versão dele: a aversão à ontologia e, em especial, à busca pela apreensão do ser-propriamente-assim da realidade efetiva não está somente na filosofia antimarxista. Justamente parte essencial da filosofia marxista contemporânea tende a ver qualquer pretensão relacionada ao desenvolvimento de uma ontologia como algo contraposto à história e correlacionada à hierarquização de categorias apreendidas de modo mais ou menos apriorístico. Mesmo em marxistas - ou neomarxistas, como quiserem - importantes como Moishe Postone (1942-2018) e Robert Kurz (1943-2012), a palavra ontologia se tornou uma espécie de palavrão. Ambos se utilizam da expressão para criticar certa posição que torna o trabalho um atributo natural e anistórico do ser social. Talvez desinformados sobre a teorização lukacsiana de obras como a Ontologia e a Estética sobre o trabalho e a ontologia, apegam-se à História e consciência de classe (1923). E, com isto, trazem certa visão ligada a leituras de Wilhelm Dilthey (I833-I9II), de Max Weber (I864-I920) e de outros autores - para que não mencionemos uma relação problemática com a filosofia hegeliana como um ponto de partida em que não há lugar para o estudo da obra tardia de Lukács.

Ainda sobre este assunto, devemos dizer que o próprio autor húngaro contribuiu para que a palavra ontologia fosse vista como um palavrão. Até o final da década de I950, ele utilizava a expressão de modo pejorativo. Ao referir-se a Georg Simmel (I85819I8), a Heidegger e a Hartmann, Lukács aponta que justamente estes procuram algo que se coloque para além das relações sociais, e que tenha um estatuto transhistórico. Nisto, diz Lukács que estes autores procuram - em uma espécie de ateísmo religioso - 
uma fundamentação anistórica e que se colocasse para além da realidade efetiva, em uma ontologia.

Ou seja, o uso lukacsiano da categoria modifica-se substancialmente no transcorrer de sua obra, e mais especificamente no final dela. E, com isto, vemos que aquilo que Kurz, Postone, entre outros, criticam nas ontologias que são contrapostas ao desenvolvimento histórico objetivo também é criticado por Lukács. Eu diria, porém, que, no final de sua vida, nosso autor vem a desenvolver sua ontologia a partir do resgate da obra de Marx em um embate bastante duro com três ontologias: a de Heidegger primeiramente, a de Hartmann de modo secundário e, no campo marxista, a ontologia de Bloch. Assim, tendo mostrar no livro como que isto se dá em relação ao autor de Ser e tempo. Procuro adentrar nos meandros deste assunto com o máximo de cuidado. Ou seja, acredito que os marxistas mencionados erram muito o alvo em certo sentido.

No que diz respeito à fenomenologia francesa, eu diria que Lukács a combateu de modo bastante decidido e duro em Marxismo ou existencialismo (1948). Este livro parece-me essencial sobre o assunto, embora - tal qual $A$ destruição da razão - possa ter, em alguns momentos específicos, uma exposição demasiado incisiva. No que é central, acredito que o livro esteja coberto de razão, porém. Principalmente, no que diz respeito à obra de Jean-Paul Sartre (1905-1980), há diversos pontos de partida importantes e interessantes para um embate marxista sobre o autor. Ao que eu saiba, com maior fôlego, Mészáros tentou desenvolver aspectos bastante relevantes sobre o tema.7 (Entre nós, Silvio Luiz de Almeida possui um trabalho interessante sobre o tema. $)^{8}$ Valorizando a postura sempre militante do pensamento do autor de Ser e o nada, porém, o autor de Para além do capital, talvez salve mais do que deve do pensamento sartreano que, como mostrou Lukács, e como reforçou Nicolas Tertulian em Lukács e seus contemporâneos, vem a ser indissociável de um dos aspectos mais problemáticos da ontologia heideggeriana, a categoria da derrelição, do estar-lançado.

Alguns aspectos destacados por Mészáros em Sartre também são um tanto quanto problemáticos, por vezes. $\mathrm{Na}$ medida em que ele deixa de valorizar parte substantiva da ontologia lukacsiana, ligado ao desenvolvimento de apontamentos sobre a questão do que fazer, ou seja, sobre a ética e a eticidade, o autor de Para além do capital talvez possua uma apreensão parcial sobre temas centrais, como a política e a ética em Lukács.

$7 \quad$ Trata-se do livro The Work of Sartre: Search for Freedom and the Challenge of History (1979; 2012), publicado no Brasil, em 20I2, com o título: A obra de Sartre: busca da liberdade e desafio da bistória. (N. da RAN)

8 Trata-se da tese Sartre: direito e politica: ontologia, liberdade e revolução, defendida em 201 e publicada em livro em 2016. Disponível em: «https://www.teses.usp.br/teses/disponiveis/2/2139/tde-19092012-I44850/ptbr.php». (N. da RAN) 


\section{REVISTA ANGELUS NOVUS}

Estes aspectos precisam ser destacados, não para desvalorizar o trabalho de um grande pensador como István Mészáros, mas para que percebamos que, por vezes, mesmo marxistas que são profundamente influenciados pela obra de Lukács vêm a deixar de lado parte importante de seu pensamento. Isto ocorre, em grande parte, com a tematização sobre a ontologia; e, assim, certas reduções equivocadas são recorrentes. Talvez a única figura de destaque no marxismo que tenha contribuído profunda e substancialmente no cenário mundial deste debate sobre a ontologia - em nível nacional, eu diria que Ester Vaisman e Ronaldo Vielmi Fortes possuem contribuições essenciais sobre o tema - tenha sido Nicolas Tertulian (1929-2019). Na obra Lukács e seus contemporâneos, ele explicita este embate com outras concepções de ontologia de modo rigoroso, cuidadoso e com uma cultura que dificilmente encontraremos entre aqueles de nossa geração. Como conhecedor das ontologias de Bloch, Hartmann, Heidegger, Sartre e outros, o autor coloca afinidades e discordâncias entre estes e Lukács, trazendo a Ontologia e a Estética para o centro do debate filosófico de qualidade. Coloca a filosofia do autor húngaro para debater com os principais expoentes da filosofia da época, e dá passos essenciais para o debate que vocês gostariam de ver como central. O filósofo italiano Guido Oldrini (1935-) certamente contribui neste debate. Porém, não com o mesmo fôlego que o autor de Lukács e seus contemporâneos.

O esforço de Tertulian é monumental. E eu não teria medo de dizer que, em meu livro, pretendi modestamente dar continuidade a este embate que o autor romeno traz à tona. A verdade, porém, é que, se eu pude dialogar de modo franco com minha orientadora e se posso debater - quando possível - com pessoas próximas como Ester Vaisman e Ronaldo Vielmi, estas são exceções. Aqui, valeria mencionar também a figura de Mário Duayer, que realizava um debate entre Postone e Lukács e que, infelizmente faleceu recentemente em decorrência de complicações com a Covid-ı. Perdemos esta grande figura devido à condução absurda da pandemia em nosso país... Enfim, as exceções vêm a confirmar a regra: o debate filosófico marxista e não marxista está um tanto quanto ensimesmado. Formam-se seitas dentro e fora da academia de modo que o debate franco é quase que impossível. Os exercícios hercúleos de um Tertulian deparam-se com a atomização dos trabalhadores da educação e dos intelectuais. E, assim, o debate de alto nível aparece como algo quase que vedado. Que fique claro: não me coloco fora disto.

Ultimamente, em vez de dar aulas sobre hermenêutica - em que o debate sobre ontologia, em verdade, é central -, passei a dar aulas de sociologia. As matérias obrigatórias que um professor universitário leciona, em grande parte, direcionam a

$22 \cdot$ ano XII, n. I7, 202I • ISSN 2I79-5487 
literatura que está estudando. Numa faculdade de Direito - e, como sabem, sou professor da faculdade de Direito da UFMG - não há matérias adequadas para que um marxista dê como marxista. E, assim, passei de uma disciplina em que a tônica acabava redundando em uma espécie de idealismo subjetivo - ou seja, justamente no que critico em meu livro - para uma em que Marx é visto como alguém que trata "somente” das relações entre classes sociais na sociedade. Ou seja, tem-se uma abordagem avessa à apreensão de uma importante dimensão do pensamento marxiano. E, assim, ele vem a ser visto pelo mesmo prisma que um autor menos sofisticado como Durkheim. Ou pior ainda, passa a ser enxergado como alguém cujas insuficiências seriam superadas por Habermas, Bourdieu, Luhmann etc. Em meio à tentativa de lecionar sobre estes autores a partir dos textos deles mesmos, certos embates - que julgo essenciais - ficam lateralizados em minhas pesquisas. Estas últimas também são direcionadas pelas orientações de um professor, que, além de pesquisador, também está credenciado na pós-graduação. E, ao menos agora, não tenho orientandos que estudem Lukács e que possam tratar de um debate mais propriamente filosófico. (Estou credenciado na pósgraduação da faculdade de Direito também.) Digo estas coisas de forte tom pessoal para destacar algo básico: as nossas teorizações, bem como nosso pensamento, trazem consigo as marcas da determinação social. No caso em tela, ela está relacionada a questões de fundo que não poderei tratar aqui e que fazem com que a universidade brasileira esteja sofrendo em diversos sentidos, mas também se ligam à posição dos intelectuais contemporâneos na divisão do trabalho e em meio a funções e a índices de produtividade que atropelam os professores e pesquisadores. Ou seja, não é somente por falta de boa vontade que o debate sério entre marxistas e não marxistas aparece como vedado. Há certamente bloqueios mais ou menos institucionalizados. Tem-se má fé também... mas o buraco, infelizmente, é mais em baixo.

O "como" disto - que, em verdade, seria essencial para que possamos compreender parte da miséria intelectual do presente - infelizmente, não poderei explicitar no espaço que dispomos. Mas diria que é essencial que compreendamos esta correlação entre desenvolvimento econômico contraditório, formação da esfera pública de uma época, a tomada de consciência sobre as oposições que são efetivas na sociedade e as categorias que são importantes à filosofia, à sociologia, e a outras ciências parcelares.

\section{WS \& HC}

A questão da manipulação aparece como uma categoria importante na Ontologia, de Lukács, observando que isso se ligaria a uma maneira de pensamento no capitalismo 


\section{REVISTA ANGELUS NOVUS}

e suas instituições, como o direito e a política se colocam. Assim, para Lukács, há uma crítica que se procura sua superação. A ratio, em Heidegger, por outro lado, tem um sentido de “um passo de volta”, remetendo sua crítica à própria modernidade, não para uma revolução social (progressista), mas olhando para o passado (reacionária). Qual é a especificidade dessa crítica da ratio em Heidegger - sobretudo em Carta ao Humanismo - e a crítica de Lukács, tendo por base a argumentação posta em seu livro: Ontologia nos extremos?

\section{VBS}

Para tratarmos da questão que colocam, é preciso dizer que, de um modo ou doutro, as coisas voltam-se a Hegel. Neste autor, a categoria da superação/supressão [Aufhebung] é central, embora tenha, por vezes, uma tonalidade fortemente idealista.

Heidegger, e outros como Nietzsche, criticam com razão o idealismo hegeliano. Porém, a natureza da crítica destes autores não os aproxima de Marx e de Lukács como quer o filósofo alemão Karl Löwith (I897-1973). Antes, afasta-os. A superação hegeliana, ao final, vem a deixar intocados os pressupostos que acredita ultrapassar e, diante disto, têm-se duas críticas possíveis ao menos: de um lado, aquela que enfatiza a necessidade de se suprimir as próprias bases reais e históricas das coisas; doutro, uma que enxerga neste ímpeto "progressista” um sintoma daquilo que é criticado. Esta última crítica é aquela de Heidegger. O autor vê Hegel como alguém imbuído de uma ontoteologia, sendo incapaz de apreender a diferença como diferença. Hegel traria, assim, uma espécie de claro-escuro - tal qual, curiosamente, Hegel critica Schelling. Os pressupostos dessa posição, assim, não poderiam ser superados. Aliás, a própria busca por uma superação estaria fadada ao fracasso. Segundo Heidegger, seria preciso, portanto, um passo de volta. Isto precisaria ocorrer diante da cotidianidade, de um lado e, doutro, face as categorias que marcam a filosofia ocidental, marcada pela metafísica e pela ontologia tradicional.

Para o autor de Ser e tempo, isto ocorreria por meio da disposição afetiva da angústia marcada pelo ser-para-a-morte - aqui não posso desenvolver todo o percurso que o autor percorre nesta correlação, infelizmente -, mas também na volta a uma concepção de verdade muito distinta daquela de Hegel - baseada na noção de verdade como adequação - e correlacionada a uma concepção de ser pré-socrática, em que ser e ente não se confundem - trata-se da famosa questão da diferença ontológica. Ou seja, a posição heideggeriana desenvolve-se com uma aversão ao progresso. Este último caracterizaria tanto a metafísica quanto a técnica da máquina e estaria presente na

\footnotetext{
$24 \cdot$ ano XII, n. I7, 202I • ISSN 2I79-5487
} 
filosofia do autor da Fenomenologia do espírito (I807). Porém, explicitamente - e isto fica claro na Carta ao bumanismo (1947) -, há muito mais: o autor de Ser e tempo, em sua crítica, coloca-se contra a concepção de história de Marx. O passo de volta heideggeriano, portanto, opõe-se à superação/supressão hegeliana e pretende defrontarse com a versão marxista do tema.

O tema por meio do qual Heidegger aproxima-se de Marx é aquele do estranhamento. Segundo a Carta ao humanismo, a dimensão da história como um processo objetivo teria sido apreendida do melhor modo por Marx, na medida em que o autor de $O$ capital aproxima a história do estranhamento. Heidegger, porém, enxerga que Marx - e Nietzsche -, mesmo sendo grandes autores da filosofia ocidental, não teriam conseguido escapar das armadilhas colocadas pela confusão entre ser e ente.

Eles teriam confundido a história com a historicidade, a razão com a ratio. Esta última, por sua vez, estaria ligada ao cálculo e a uma postura agressiva diante dos entes. E o resultado do império da ratio estaria, como já mencionado, tanto nos tratores agrícolas quanto nos campos de concentração. De acordo com a visão heideggeriana, o desenvolvimento moderno da razão redundaria em uma espécie de esquecimento - o famoso esquecimento do ser -, tendo-se como ápice deste desenvolvimento progressivo Marx e Nietzsche. A crítica heideggeriana, portanto, volta-se primariamente contra Hegel, mas procura atingir os dois autores que acabo de mencionar. E tem como enfoque, no caso de Marx, a noção de superação/supressão. Com isto, tem-se uma crítica heideggeriana à modernidade e à razão. Esta última, em verdade, segundo Heidegger, deveria ser vista de modo mais originário, remetendo-se ao discurso e à concepção de verdade como alethea, como mostra o autor no famoso parágrafo 7 de $\mathrm{Ser}$ e tempo.

Heidegger busca um passo de volta tanto diante do progresso quanto diante da filosofia moderna e da própria modernidade. Porém, há um ponto mais importante.

Sua visão sobre a esfera pública e o cotidiano faz com que ele se coloque contra aquilo que chama de falatório e de ditadura da opinião pública. E eles, em verdade, incorporam-se na moderna democracia. Lukács, neste sentido, diz que um dos pontos centrais da posição heideggeriana é sua posição avessa à democracia. Estando a esfera pública marcada pelo estranhamento e pela reificação, segundo Heidegger, não haveria como não haver certa perda de si neste campo. Em determinado momento, o autor de Ser e tempo - em consonância com sua posição sobre a metafísica, a técnica e a fundação de Estados - veio a defender uma espécie de revolução, em verdade. Mas ela não levaria o tempo histórico adiante. Antes, de acordo com a grandeza do acontecimento do nacional-socialismo, ela revolveria o ser-aí ocidental podendo levar a 


\section{REVISTA ANGELUS NOVUS}

uma posição mais originária e conforme com aquilo que caracterizaria o próprio povo alemão de modo mais autêntico.

Porém, como mencionei, no final da década de 1930, a posição do autor já é outra. E, deste modo, ele traz uma correlação negativa com a técnica, com a metafísica, e com o acontecimento do nacional-socialismo. Destaca, assim, uma posição mais voltada à crítica ao esquecimento, à ratio. $\mathrm{E}$, com isto, preciso destacar: mesmo que de modo mediado, em verdade, ele se coloca contra elementos profundamente manipulatórios que marcam o capitalismo. Mas, claro, não coloca as coisas nestes termos, como podem perceber. E, ao deixar de trazer esperanças no sentido de um revolver da própria história, vem a colocar a questão de tal modo que, ao fim, está vedada uma transformação substantiva do presente. Quanto teve esperanças neste sentido, apoiouse em algo, para dizer o mínimo, problemático. E estes aspectos, como pretendo demonstrar em meu livro, não são elementos acidentais à teoria heideggeriana. Em verdade, são essenciais a esta.

Lukács, por sua vez, coloca a questão em outros termos. Admite, porém, a perspicácia da crítica heideggeriana à cotidianidade presente principalmente em Ser e tempo. O autor da Ontologia, deste modo, desenvolve uma teoria sobre o cotidiano tanto na mencionada obra quanto na Estética - principalmente no primeiro volume - e nas entrevistas do final de sua vida. Nestas últimas, bem como na Ontologia, defende uma democracia da vida cotidiana - democracia socialista - contra o aspecto manipulatório que critica. E para tratar deste aspecto, não se volta contra qualquer espécie de esquecimento, ou de diferença ontológica. Para ele, estas são formas extremamente idealistas de colocar o tema. Lukács procura demonstrar como que o desenvolvimento da esfera pública burguesa depende do próprio capitalismo, em que o cidadão sucumbe ao burguês.

Ou seja, o enfoque está na apreensão reta da história como processo objetivo.

Com a decadência da burguesia, a pretensão de um Estado que possa conciliar os antagonismos da sociedade civil-burguesa esvai. Explicitamente, já se sabe que o Estado é um servo da sociedade capitalista. No que diz respeito às formas ideológicas e à esfera pública, há, de acordo com Lukács, consequências importantes: a defesa do capitalismo se torna direta ou indiretamente apologética. De um lado, tem-se um pensamento em que a razão se reduz à realidade efetiva de uma sociedade irracional. Doutro, uma teorização em que se busca uma espécie de terceiro termo, criticando-se a própria razão de modo mais ou menos idealista. Lembremos que a busca por uma forma racional, comunitária e consciente de lidar com as condições materiais de existência - o reino da necessidade, para que se use a posição de Marx em $O$ capital - é um pressuposto para 
que possam emergir interrelações que não se subordinem à posição dos indivíduos na divisão do trabalho. Com isto, tem-se tanto a apologia direta da razão irracional capitalista - o que Heidegger também critica - quanto a apologia indireta, caracterizada, dentre outros aspectos, por considerar o trabalho, as condições materiais de existência como algo essencialmente relacionado à reificação e a certa divisão hierárquica do trabalho.

Esta última posição, com muitas mediações, procuro demonstrar em meu livro, acaba por ser a de Heidegger. Lukács, neste sentido específico, diz que o autor alemão é tanto contrário à democracia quanto traz em sua filosofia um ímpeto irracionalista.

Lukács avança no assunto, demonstrando como que, em sua época, há certa oscilação entre um racionalismo crasso e formalista e um irracionalismo no modo de se posicionar diante das relações sociais capitalistas. Este oscilar traz consigo as posições de classe ao mesmo tempo em que o faz de um modo bastante característico: a manipulação começa a fazer parte do modus operandi normal da sociedade capitalista. $\mathrm{Na}$ ampliação do capital ao setor de serviços de modo mais proeminente, no consumo e no Estado tem-se um lado da coisa. E isto é admitido mesmo por autores comprometidos com a ordem do capital, como o economista canadense-estadunidense John Kenneth Galbraith (1908-2006), por exemplo - Lukács o cita recorrentemente sobre o tema. Porém, há outro aspecto do tema: a manipulação positivista começa a marcar a esfera estatal e jurídica de modo bastante claro. Nelas, a questão aparece pela oscilação mencionada, cuja função última vem a ser a adequação àquilo que está pressuposto pelo Direito: a reposição das relações capitalistas de produção. Se elas, muitas vezes, não podem ser colocadas em um patamar superior, defende-as mesmo assim. E, com isto, o comprometimento com qualquer conceito sério de racionalidade esvai-se. Um modo racional de lidar com a esfera pública, com a produção e com as personalidades aparece como algo fora de questão.

E, contrariamente a esta posição, Lukács defende no final de sua vida que, na produção, seria preciso indivíduos livremente associados e, na esfera pública, deveria aparecer o que chama de democracia da vida cotidiana. Nesta última, ter-se-ia supressão da oposição entre burguês e cidadão, bem como a participação que rompesse, não só com a divisão escravizadora do trabalho que caracteriza a sociedade capitalista, mas também com a oposição entre trabalho material e trabalho intelectual. Estes últimos passariam a se integrar e interagir de modo não mais opositivo, ocorrendo o mesmo com a relação entre a cidade e campo. A volta lukacsiana a Marx, assim, vem a redundar em críticas tanto à manipulação capitalista quanto às sociedades que se colocam como subordinadas de um modo mais ou menos mediado à União Soviética. A superação dos 


\section{REVISTA ANGELUS NOVUS}

elementos manipulatórios - presentes também nos países alinhados à União Soviética -, portanto, precisariam, mais do que nunca, de uma decidida posição socialista. E isto se daria tanto diante do capitalismo manipulatório quanto do socialismo que Lukács via como algo a ser desenvolvido em sua forma condizente com as possibilidades do presente. Também por esta posição não é de se estranhar que nosso autor seja deixado de lado pelos filósofos contemporâneos.

\section{WS \& HC}

Uma derradeira questão: em sua visão, diante de suas pesquisas, é possível pensar que a trama heideggeriana em Ser e Tempo poderia dialogar com História e consciência de classe, como chegou a sugerir Nicolas Tertulian? E ainda: a Ontologia do ser social pode ser pensada como uma obra que responderia às questóes pelas quais Martin Heidegger tocou de um modo distinto de um trato marxista?

\section{VBS}

A questão do estranhamento e da reificação pairavam no ar, como disse Lukács no "Prefácio de 1967 " de História e consciência de Classe. Elas apareciam em Simmel e em Heidegger, por exemplo. No entanto, procurar trazer a influência da obra lukacsiana de 1923 a tal ponto de Ser e tempo (1927) ser uma espécie de resposta a ela talvez seja exagero.

Esta posição é defendida por Lucien Goldmann, que vê várias homologias estruturais entre as duas obras. No entanto, tendo a acreditar que a própria análise goldmanniana vem a deixar de trazer à tona um aspecto decisivo da crítica marxista: a apreensão da diferença específica na constituição das formações ideais e das funções destas últimas. Em Para uma nova filosofia (1973), há uma aproximação entre o conceito lukacsiano de totalidade e a categoria de ser em Heidegger. Goldmann indica corretamente que ambos os autores, de certo modo, contrapóem-se ao neokantismo e às antinomias da razão pura - que Lukács lê a partir do que chama de antinomias do pensamento burguês. Porém, este posicionamento contra o neokantismo não é algo que esteja presente somente nos dois pensadores. Tal qual a questão do estranhamento, isto pairava no ar. Ou seja, Heidegger e Lukács compartilham alguns temas - tanto em 1923-1926 quanto na década de 1970 - porém isto não decorre de um diálogo implícito inconfessável. O que o livro de Goldmann enfatiza são questóes, de certo modo correlatas. Mas, o que é preciso trazer à tona, e que procurei fazer em meu livro, é 
apontar as diferenças específicas entre os pensadores. E elas vão desde o modo de proceder diante do pensamento pretérito (passo de volta $\times$ superação/supressão), passam pela concepção de trabalho e por colocações mais gerais sobre a alienação e o estranhamento - Heidegger não diferencia ambos - e chegam nos posicionamentos sobre a esfera pública, a história e a historicidade. A análise imanente das formas ideológicas precisa apreender a estrutura dos pensamentos dos autores que compara de modo o mais cuidadoso possível.

Tertulian realiza tal escavação em minha opinião. É um leitor bastante sério de Heidegger e seus textos sobre a ontologia heideggeriana - em comparação com a lukacsiana - são preciosidades. E ele está corretíssimo ao apontar que a obra tardia de Lukács depara-se com alguns de seus contemporâneos como Heidegger, Bloch e Hartmann, para que mencionemos os mais importantes na tematização da ontologia.

Porém, por vezes, o autor de Lukács e seus contemporâneos vem a exagerar no caráter de "resposta" de Lukács a Heidegger. Ele destaca aspectos essenciais, certamente. Porém, em alguns textos, suas afirmações são muito peremptórias sobre o assunto. Tendem a ver uma relação mais direta do que realmente existe na obra dos autores. De certo modo, eu diria que se tem algo bastante mais basilar: as formas ideológicas possuem uma função social específica e trazem consigo uma posição. E estes importantes autores se posicionam, primeiro, diante do capitalismo em sua fase imperialista, depois, frente ao capitalismo tardio, chamado por Lukács de manipulatório. Trata-se de autores perspicazes o suficiente para posicionarem-se coerentemente e com uma base filosófica que pode ser exemplar a outros pensadores. De certo modo, ambos tratam de questóes comuns. Neste sentido específico, respondem questões que também foram colocadas em embate.

Tem-se, portanto, um embate entre as filosofias de Heidegger e de Lukács. Ou seja, a análise conjunta das filosofias destes autores é muito proveitosa. De um lado, tem-se uma defesa sofisticada e decidida do marxismo e do socialismo. Doutro, são colocadas categorias que influenciarão todo o pós-estruturalismo, bem como diversas concepções teóricas e hermenêuticas. Se talvez tenha havido um tempo em que - para que se use a dicção do historiador francês da filosofia, François Dosse (1950-) - todos foram inspirados por Nietzsche, hoje Heidegger é uma influência essencial à filosofia e mesmo à historiografia, ao Direito, e a muitos outros campos.

As visões que enfatizam aspectos hermenêuticos, caso queiram ser sérias, acabam por passar pelo autor de Ser e tempo ou por pensadores que são profundamente influenciados por ele, como Hans-Georg Gadamer (1900-2002), por exemplo. Eu diria, neste sentido, que as melhores versões de teorias contrárias ao pensamento marxista 


\section{REVISTA ANGELUS NOVUS}

possuem uma extração heideggeriana ao passo que uma defesa bastante consequente $\mathrm{da}$ importância do marxismo está em György Lukács. Por exemplo: se formos ver algumas linhagens da teoria contemporânea, notaremos que um autor sério como Enrique Dussel (1934-), teve sua formação passando por Paul Ricour (1913-2005), que por sua vez, debateu muito com a teoria heideggeriana. Neste sentido, mesmo a vertente mais marxista do pensamento decolonial passa por certo flerte com temáticas do heideggerianismo. Ou seja, o embate Heidegger-Lukács passa por categorias essenciais à filosofia - sujeito, ontologia, ser, estranhamento, história, dentre outras -, remete à compreensão do conturbado século XX e das diferentes posições diante dele, leva à problematização sobre a técnica e muitas outras coisas. Porém, chega ao nosso tempo também. Acredito que se têm posições prototípicas da maior sofisticação possível na compressão e transformação da realidade. Os temas colocados pelos autores ainda são essenciais, sua lida com a filosofia é sofisticada e séria e se trata, assim, de teorias ainda inescapáveis. Neste sentido, eu diria que o embate Heidegger-Lukács é tanto algo ligado ao nosso passado imediato quanto àquilo que há de mais importante na compreensão do presente. E se abandonamos os debates de alto nível, resta somente praguejar sobre "disputas de narrativas" e outras coisas que, infelizmente, são moeda corrente e que possuem a profundidade de um pires.

A ignorância não leva muito adiante. Aliás, vem levando cada vez mais longe da compreensão da realidade de nossa época. E, infelizmente, o fundo do poço ainda pode estar longe de ser alcançado. Com uma esquerda supostamente crítica ao elitismo das teorias mais elaboradas e sérias, tem-se uma outra forma de apologia indireta ao capitalismo, criticada por Lukács. Ela, inclusive, depende de certa visão hermenêutica que não deixa de se relacionar com certa leitura de Heidegger. Mas isto é um assunto para outro momento.

Gostaria de terminar somente manifestando minha preocupação: talvez parte considerável da esquerda, ao distanciar-se do pensamento marxista cada vez mais, esteja em um atoleiro bastante perigoso. E acredito que colocar embates pesados e densos como aquele existente entre Heidegger e Lukács pode ajudar a esclarecer alguns fundamentos disto. 